\title{
Exercise assessments and trainings of pulmonary rehabilitation in COPD: a literature review
}

This article was published in the following Dove Press journal:

International Journal of COPD

\author{
Yuqin Zeng ${ }^{1-3}$ \\ Fen Jiang ${ }^{1-3}$ \\ Yan Chen ${ }^{1-3}$ \\ Ping Chen ${ }^{1-3}$ \\ Shan $\mathrm{Cai}^{1-3}$ \\ 'Department of Pulmonary and \\ Critical Care Medicine, the Second \\ Xiangya Hospital, Central South \\ University, Changsha, Hunan, 4I00II, \\ China; ${ }^{2}$ Research Unit of Respiratory \\ Disease, Central South University, \\ Changsha, Hunan 4I00II, China; \\ ${ }^{3}$ Hunan Diagnosis and Treatment \\ Center of Respiratory Disease, \\ Changsha, Hunan 4I00II, China
}

\begin{abstract}
Skeletal muscle dysfunction leads to reduction in activity in patients with COPD. As an essential part of the management of COPD, pulmonary rehabilitation (PR) alleviates dyspnea and fatigue, improves exercise tolerance and health-related quality of life, and reduces hospital admissions and mortality for COPD patients. Exercise is the key component of PR, which is composed of exercise assessment and training therapy. To evaluate PR's application in clinical practice, this article summarizes the common methods of exercise measurement and exercise training for patients with COPD. Exercise assessments should calculate patients' symptoms, endurance, strength, and health-related quality of life. After calculation, detailed exercise therapies should be developed, which may involve endurance, strength, and respiratory training. The detailed exercise training of each modality is mentioned in this review. Although various methods and therapies of PR have been used in COPD patients, developing an individualized exercise training prescription is the target. More studies are warranted to support the evidence and examine the effects of long-term benefits of exercise training for patients with COPD in each stage.
\end{abstract}

Keywords: COPD, pulmonary rehabilitation, exercise assessment, exercise training

\section{Introduction}

COPD is a common pulmonary disease worldwide and is characterized by progressively persistent airflow limitation. ${ }^{1}$ The economic and social burden of COPD is substantial and increasing. COPD will be the seventh leading cause of disabilityadjusted life years and the fourth leading cause of death in $2030 .^{2}$ Daily symptoms such as chronic and progressive dyspnea, cough, and sputum production deserve the blame for the burden and lead to activity limitation and ultimately COPD patients' inability to work and take care of themselves. ${ }^{3}$ Patients with COPD are trapped in a vicious circle of inactivity, which begins with breathlessness. ${ }^{4}$ The exertional dyspnea of COPD patients is usually multifactorial, partly reflecting peripheral muscle dysfunction, ${ }^{5}$ dynamic hyperinflation, ${ }^{6}$ and higher fat mass. ${ }^{7}$ Some of these factors are amenable to exercise training incorporated as a major component of a pulmonary rehabilitation (PR) program.

$\mathrm{PR}$ is defined as a "comprehensive intervention based on a thorough patient assessment followed by patient-tailored therapies that include, but are not limited to, exercise training, education and behavior change, designed to improve the physical and psychological condition of people with chronic respiratory disease and to promote the long-term adherence to health-enhancing behaviors". ${ }^{8} \mathrm{PR}$ is an essential part of the management of COPD, alleviating dyspnea and fatigue, improving exercise tolerance and health-related quality of life, and reducing hospital admissions 
and mortality in COPD patients. ${ }^{9,10}$ Exercise training is the cornerstone of PR and includes many types of training, such as ground walking exercise training, cycling training, resistance training, water-based exercise training, Tai Chi, and so on. The type of training most suitable for COPD patients depends on their physiologic requirements and individual demands. This review focuses on the physical pathology of COPD, exercise assessment methods, and trainings for COPD patients.

\section{Physical pathology Skeletal muscle dysfunction}

Skeletal muscle dysfunction, which is affected by skeletal muscle performance (strength and endurance) and structure (fiber size, fiber type distribution, capillary density, and metabolic capacity), due to deconditioning leads to less activity in patients with COPD. ${ }^{11}$ Skeletal muscle function is largely dependent on the physiologic structural components of a muscle, especially the fibers.

\section{Fiber type shift}

The speed of fiber contraction and predominant type of metabolism inversely determine their resistance to fatigue and are the most relevant physiologic features. Type I fibers, which are slow-twitch fibers and very resistant to fatigue, are composed of myosin heavy-chain (MyHC) type I. Type IIx are fast-twitch fibers and have low resistance to fatigue, and they are made up of MyHC type IIx. A previous study reported that a fiber type I proportion $<27 \%$ can be considered as abnormally low. Likewise, a fiber type IIX proportion $>29 \%$ can be regarded as abnormally high. ${ }^{12}$ In COPD patients, the proportion of type I fiber is smaller than in healthy persons and is accompanied by an increase in type IIb fiber, which might be an important factor in increased leg muscle fatigability and reduced endurance. ${ }^{13}$

\section{Muscle fiber atrophy}

Muscle fiber atrophy is a major systemic impairment in COPD. Respiratory and limb muscles are usually affected in these patients, thus contributing to impaired muscle function, poor exercise capacity, and reduced health status. The reduction in muscle fiber cross-sectional area (CSA) is a generally accepted marker of muscle atrophy and can be a predictor of mortality in COPD. ${ }^{14}$ Midthigh muscle CSA has been found to predict survival in patients with moderate-to-severe COPD, ${ }^{15}$ and the mid-arm muscle area can also predict mortality in COPD patients. ${ }^{16}$ An imbalance between protein degradation and synthesis, which is enhanced by reduced regenerative repair leads to muscle wasting. The recruitment of key components of ubiquitinmediated proteolytic systems, such as Atrogin-1 and Nedd4, can regulate protein degradation and myostatin, a negative regulator of muscle growth. ${ }^{17}$ Insulin-like growth factor-1 is sufficient to induce skeletal muscle hypertrophy, and in patients with COPD, it is decreased during an acute exacerbation. ${ }^{18}$

\section{Hyperinflation}

One critical characteristic of COPD patients is hyperinflation, occurring either at rest (static hyperinflation) or during exercise (dynamic hyperinflation), which can be expressed by functional residual capacity (FRC) or end-expiratory lung volume (EELV). ${ }^{19}$ Static hyperinflation is a decrease in the inward elastic recoil of the lungs without changes of the elastic properties in the chest wall due to pulmonary emphysema. In COPD patients with emphysema, the lung recoil pressure is further reduced by a reduced elastic load, resulting in a larger FRC or EELV. ${ }^{20}$ Dynamic hyperinflation is defined as an increase in FRC or EELV above the resting value during periods of dynamic forces such as exercise. ${ }^{21}$ During exercise, to accommodate additional respiratory demands, respiratory rate and tidal volume are increased. ${ }^{22} \mathrm{~A}$ faster respiratory rate allows less time for exhalation. In COPD patients, decreased lung elastic recoil pressure and increased airways resistance lead to an increase in the mechanical time for lung emptying. Thus, insufficient exhalation causes an increase in operational lung volumes and progressive air retention called "air trapping", resulting in dyspnea. ${ }^{23}$

\section{Exercise assessment methods}

The assessment of patients and program outcomes is a crucial element of a PR program. ${ }^{24}$ Before training, rehabilitation therapists should measure the condition of patients, including symptoms, endurance and strength, health-related quality of life, and so on. As well as during and after a certain time of training, we should reassess patient performance and program effectiveness.

\section{Symptom evaluation}

For COPD patients, dyspnea is the most common symptom. Before, during, and after PR, it is important to identify and evaluate the symptom as a guide for training. Some of the common methods to calculate breathlessness are listed in Table 1. The modified Medical Research Council (mMRC) dyspnea scale is a five-grade scale that ranges from 0 to 4 based on various physical activities. ${ }^{25}$ It allows either self- or interviewer administration. An $\mathrm{mMRC}$ of $\geq 2$ is considered 
Table I Assessment of symptom evaluation in patients with COPD

\begin{tabular}{|c|c|c|c|c|c|}
\hline Items & $\begin{array}{l}\text { Assessment } \\
\text { methods }\end{array}$ & Function & Advantage & Disadvantage & MCID \\
\hline \multirow[t]{5}{*}{ Dyspnea } & $\mathrm{mMRC} 25$ & $\begin{array}{l}\text { Rates dyspnea and measures } \\
\text { disability levels }\end{array}$ & Short completion time (30 seconds) & $\begin{array}{l}\text { Only cover } \\
\text { breathlessness }\end{array}$ & 2 units \\
\hline & Borg ${ }^{26}$ & $\begin{array}{l}\text { Measures intensity of the sensation } \\
\text { of breathlessness and leg fatigue }\end{array}$ & $\begin{array}{l}\text { Quick and easy, can be used over } \\
\text { the phone }\end{array}$ & - & I unit \\
\hline & VAS $^{29}$ & Measures breathlessness & $\begin{array}{l}\text { Within-subject repeated } \\
\text { measurement }\end{array}$ & $\begin{array}{l}\text { Not suitable to compare } \\
\text { in different patients }\end{array}$ & $10-20$ units \\
\hline & $\mathrm{NRS}^{31}$ & Measures dyspnea & $\begin{array}{l}\text { A valid measure of present dyspnea, } \\
\text { and more repeatable than the VAS }\end{array}$ & $\begin{array}{l}\text { Need smaller sample } \\
\text { sizes to detect a change }\end{array}$ & - \\
\hline & $\mathrm{BDI} / \mathrm{TDI}^{32}$ & $\begin{array}{l}\text { Measures dyspnea and the change } \\
\text { with time }\end{array}$ & $\begin{array}{l}\text { Valid, responsive measures of acute } \\
\text { changes }\end{array}$ & $\begin{array}{l}\text { Only cover } \\
\text { breathlessness }\end{array}$ & I unit \\
\hline OCD & $\begin{array}{l}\text { A variation of } \\
\text { the } \mathrm{VAS}^{33}\end{array}$ & $\begin{array}{l}\text { Calculates oxygen cost at different } \\
\text { activity levels }\end{array}$ & Simple and easy to administer & $\begin{array}{l}\text { Responsiveness and } \\
\text { validity are unproved }\end{array}$ & - \\
\hline
\end{tabular}

Abbreviations: MCID, minimal clinically important difference; mMRC, modifed Medical Research Council; VAS, Visual Analogue Scale; NRS, Numeric Rating Scale; BDI, Baseline Dyspnea Index; TDI, Transition Dyspnea Index; OCD, oxygen-cost diagram.

as the cut point for distinguishing "less breathlessness" from "more breathlessness". ${ }^{1}$ The Borg CR-10 scale ${ }^{\circledR}$ is a category score that ranges from "Nothing at all" to "Maximal" based on breathlessness and leg fatigue. ${ }^{26,27}$ One unit is regarded as the minimum important difference for the scale. ${ }^{28}$ Generally, the Borg scale has been used before and after the 6-minute walking test (6-MWT) to calculate breathlessness and leg fatigue. The Visual Analogue Scale (VAS) is one method that has been used to measure dyspnea. ${ }^{29}$ It is a $100 \mathrm{~mm}$ horizontal or vertical line, changing approximately every 10-20 units as the recommended minimal clinically important difference (MCID). ${ }^{30}$ Other than the VAS, the numeric rating scale (NRS) is a 0-10 ("no breathlessness at all" to "the worst breathlessness imaginable") scale that measures presence of dyspnea. It can be used over the phone and is more repeatable than the VAS. ${ }^{31}$ The Baseline Dyspnea Index (BDI), as its name indicates, calculates the initial baseline assessment of breathlessness. To explore any changes in dyspnea with respect to the baseline condition, the Transitional Dyspnea Index (TDI) has been used after therapy or PR. A variation of 1 unit in the TDI score is considered as the MCID. ${ }^{32}$ The oxygen-cost diagram is a $100 \mathrm{~mm}$ vertical line-oriented VAS that calculates oxygen cost at different activity levels during activities of daily living. ${ }^{33}$

\section{Exercise capacity assessment}

Exercise capacity is measured by endurance and strength.

\section{Endurance assessment}

Generally, the most common method used to calculate endurance is the field test, such as the 6-minute walk test (6MWT), ${ }^{34}$ the incremental shuttle walking test (ISWT), and the endurance shuttle walking test (ESWT) (Table 2). ${ }^{35}$ The 6MWT is a self-paced test with an MCID of 30 meters (m). The shuttle walking tests are externally paced and controlled by a series of pre-recorded signals. The MCID of the ISWT for COPD patients is $48 \mathrm{~m}^{36}$ The ESWT is a derivative of the ISWT using the same $10 \mathrm{~m}$ shuttle course and an audio signal to control pace, with an MCID of 65 seconds or $95 \mathrm{~m} .^{37,38}$ The $4 \mathrm{~m}$ gait speed is a simple functional assessment tool used in community-dwelling older adults ${ }^{39}$ and has been verified reliable in COPD, with an MCID of $0.11 \mathrm{~m} / \mathrm{s} .{ }^{40} \mathrm{In}$ addition, a new field test, the 6-minute stepper test, has been identified as a reproducible, sensitive, secure, well-tolerated, and feasible test for patients with COPD. ${ }^{41}$ It records the largest number of steps on a stepper for 6 minutes with an MCID of $\sim 20$ steps. $^{42}$ In recent years, the sit-to-stand test (STST), an easy-to-use field test, has been applied to evaluate exercise tolerance in patients with COPD. ${ }^{43}$ Among different versions and lengths, the 1-minute STST is the most widely used version with an MCID of 3 repetitions. ${ }^{44}$

The cardiopulmonary exercise test (CPET) has long been the gold standard method for assessment of exercise capacity in COPD, using a cycle ergometer to measure the indexes of cardiac and pulmonary performance, such as maximum oxygen consumption $\left(\mathrm{VO}_{2} \max \right){ }^{45}$ The rate of decline in $\mathrm{VO}_{2}$ max in the USA is $\sim 10 \%$ per decade for normal people. ${ }^{46}$ The common exercise types used in the CPET are the incremental (or ramp) exercise test, maximal incremental treadmill test, and the constant work-rate exercise test. Compared with the 6MWT, the CPET is more expensive and requires additional measurements. ${ }^{47}$

\section{Strength assessment}

Strength has marked decrements in COPD patients, especially in severe patients (Table 3 ). It is necessary to identify peripheral muscle weakness (including limb and respiratory 
Table 2 Assessment of exercise endurance in patients with COPD

\begin{tabular}{|c|c|c|c|c|}
\hline $\begin{array}{l}\text { Assessment } \\
\text { methods }\end{array}$ & Function & Advantage & Disadvantage & MCID \\
\hline \multicolumn{5}{|l|}{ Field test } \\
\hline $6 \mathrm{MWT}^{34}$ & Evaluates functional capacity & $\begin{array}{l}\text { Easy, cheap, better tolerated, } \\
\text { and more reflective of } \\
\text { activities of daily living }\end{array}$ & $\begin{array}{l}\text { Very sensitive } \\
\text { to variations in } \\
\text { methodology and } \\
\text { environment }\end{array}$ & $30 \mathrm{~m}$ \\
\hline $\mathrm{ISWT}^{36}$ & $\begin{array}{l}\text { Measures cardiopulmonary exercise } \\
\text { capacity }\end{array}$ & $\begin{array}{l}\text { Provokes a similar physiological } \\
\text { response to CPET }\end{array}$ & $\begin{array}{l}\text { Needs a } \\
\text { prerecorded signal }\end{array}$ & $48 \mathrm{~m}$ \\
\hline ESWT $^{37}$ & Calculates endurance capacity & $\begin{array}{l}\text { More sensitive to change than } \\
6 \mathrm{MWT}\end{array}$ & $\begin{array}{l}\text { Must enforced } \\
\text { after ISWT }\end{array}$ & $\begin{array}{l}65 \text { seconds } \\
\text { or } 95 \mathrm{~m}\end{array}$ \\
\hline $4 M^{4} S^{39}$ & $\begin{array}{l}\text { A marker of exercise capacity and a } \\
\text { consistent risk factor for disability }\end{array}$ & Reliable and quick to perform & $\begin{array}{l}\text { Usually used in } \\
\text { older adults or } \\
\text { frail individuals }\end{array}$ & $0.11 \mathrm{~m} / \mathrm{s}$ \\
\hline $6 \mathrm{MST}^{41,42}$ & $\begin{array}{l}\text { An evaluation of exercise tolerance } \\
\text { and used to individualize aerobic } \\
\text { training }\end{array}$ & $\begin{array}{l}\text { Avert the environmental } \\
\text { constraints of the } 6 \mathrm{MWT}\end{array}$ & $\begin{array}{l}\text { Safety concerns } \\
\text { on the stepper }\end{array}$ & 20 steps \\
\hline $\begin{array}{l}\text { STST }^{43,44} \\
(\text { I-minute })\end{array}$ & $\begin{array}{l}\text { An easy-to-use field test to evaluate } \\
\text { exercise tolerance }\end{array}$ & $\begin{array}{l}\text { A reliable, valid, and responsive } \\
\text { test and comparable to } 6 \mathrm{MWT}\end{array}$ & $\begin{array}{l}\text { Need to be more } \\
\text { widespread }\end{array}$ & 3 repetitions \\
\hline $\mathrm{CPET}^{45}$ & $\begin{array}{l}\text { Identifies the reasons of exercise } \\
\text { limitation, assesses maximal } \\
\text { exercise capacity, and the prognosis }\end{array}$ & $\begin{array}{l}\text { Standard aerobic exercise } \\
\text { testing assessment }\end{array}$ & $\begin{array}{l}\text { Carries an } \\
\text { additional cost } \\
\text { and competency } \\
\text { requirements }\end{array}$ & - \\
\hline
\end{tabular}

Abbreviations: MCID, minimal clinically important difference; 6MWT, 6-minute walk test; ISWT, incremental shuttle walking test; ESWT, endurance shuttle walking test; 4MGS, 4-metre gait speed; 6MST, 6-minute stepper test; STST, sit-to-stand test; CPET, cardiopulmonary exercise testing.

strength) before and after PR to prescribe appropriate resistance training loads.

In clinical and research settings, volitional or nonvolitional techniques are used to measure strength. The former includes manual muscle testing (MMT), which is a rough assessment tool used for COPD patients, especially in the critical care setting. ${ }^{48}$ Handheld dynamometry can provide more quantitative information than MMT. It is suitable to assess changes in muscle strength for groups of people with COPD, but it is not suitable for one person. ${ }^{49}$ Handgrip dynamometry is used to evaluate handgrip strength, especially in aging adults as a predictor of mortality and physical function. ${ }^{50}$ Computerized dynamometry, such as the Cybex, Biodex, and Kin-Com, is used to measure isokinetic and isometric strength of various muscle groups at different joint angles and contraction velocities. ${ }^{51}$ Strain gauge is a simple and portable tool to measure maximal voluntary contraction of quadriceps and isometric knee extension tension in COPD patients, which is equipped with a semi-recumbent chair. ${ }^{52,53}$ Furthermore, the one-repetition maximum (1RM) test is defined as the maximal weight that can be lifted once using a proper lifting technique. It is regarded as the gold standard for assessing muscle strength in nonlaboratory situations. ${ }^{54}$ The $1 \mathrm{RM}$ is a reliable and well-tolerated method used in PR programs for individuals with COPD. ${ }^{55}$ All of the above testing methods may be affected by the patient's ability, testers, and other external factors. Therefore, the nonvolitional technique has been used to calculate muscle force, most commonly in quadriceps. Supramaximal electrical nerve stimulation was used to measure the maximal voluntary contraction force but is not popular because of its discomfort and technical difficulty. Subsequently, the relatively painless magnetic nerve stimulation has emerged to assess skeletal muscle strength in patients with COPD. ${ }^{56}$

Impairment of (inspiratory and expiratory) respiratory muscles is a common clinical finding in patients with COPD.${ }^{57}$ Early detection of respiratory muscle weakness is necessary to prevent and intervene with respiratory failure. Some measures including volitional or nonvolitional techniques are shown in Table 3. Maximal inspiratory pressure (MIP) and maximal expiratory pressure are easy, portable, well-tolerated, and noninvasive indices of respiratory muscle strength at the mouth. ${ }^{58}$ In different populations, the reference values of the lower limit of normal are diverse. ${ }^{59}$ Sniff tests, such as sniff esophageal pressure (Sniff Pes), sniff nasal inspiratory pressure (SNIP), and sniff transdiaphragmatic pressure (Sniff Pdi), are performed with catheters through one or both unobstructed nostrils to calculate respiratory muscle strength. ${ }^{6}$ Sniff Pes, performed with a balloon catheter, is a useful test of inspiratory muscle strength and an alternative 


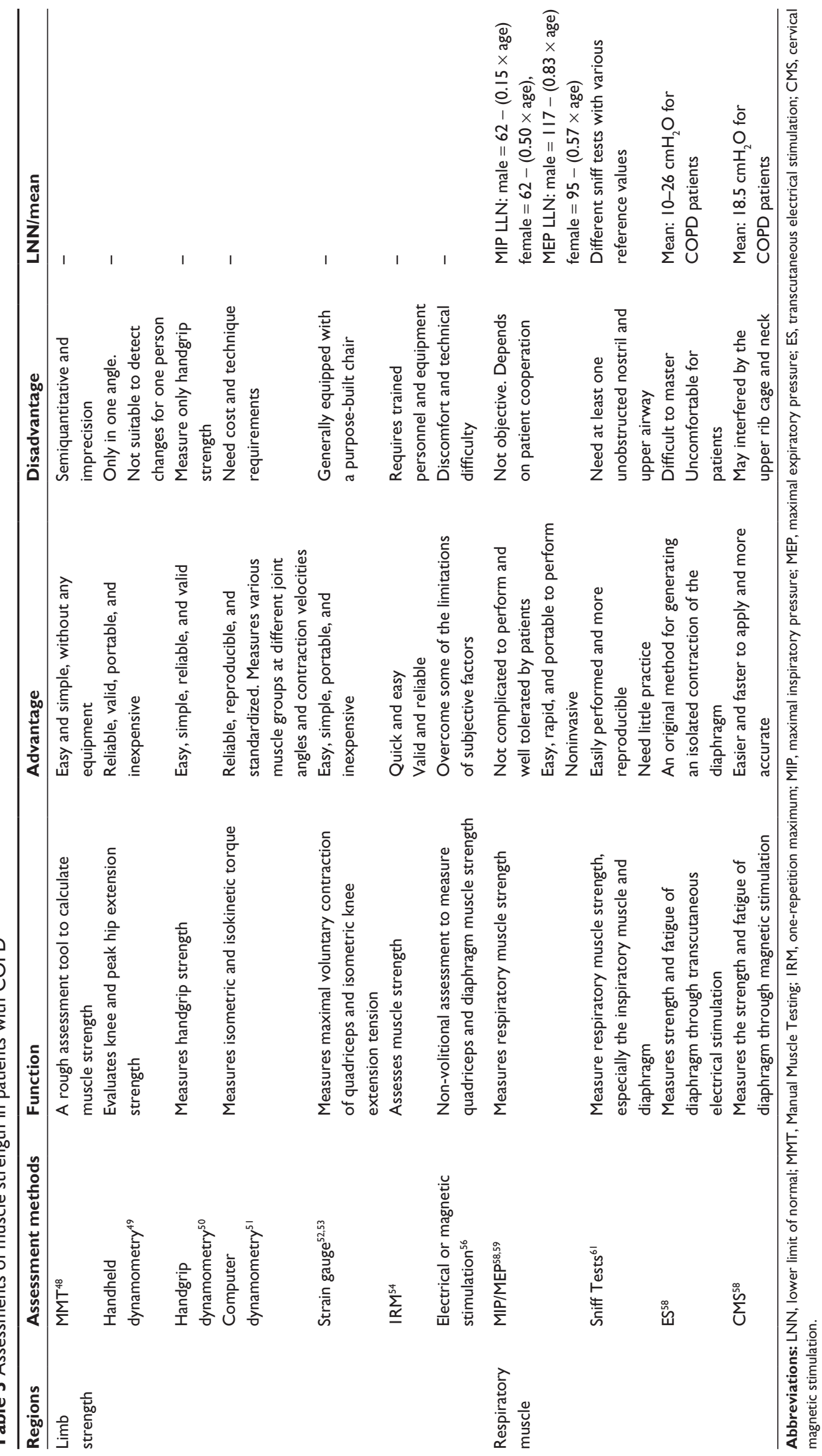


method in patients who are unable to cooperate with the MIP maneuver. ${ }^{61}$ SNIP is recommended as a complement to MIP for assessing inspiratory muscle strength in patients with COPD. Unlike the Sniff Pes, SNIP is performed with a polyethylene catheter in an occluded nostril during a maximal sniff through the contralateral nostril. ${ }^{62}$ Sniff Pdi is measured with various kinds of catheters, such as balloon or fluid-filled catheters. It is used to assess the strength of the diaphragm, which is the main inspiratory muscle. ${ }^{63}$ Nonvolitional techniques include transcutaneous electrical phrenic nerve (ES) stimulation and cervical magnetic stimulation (CMS) ${ }^{58}$ The mean value of CNS in COPD patients is $18.5 \mathrm{cmH}_{2} \mathrm{O}$, and for the $\mathrm{ES}$ is $10-26 \mathrm{cmH}_{2} \mathrm{O} .{ }^{64,65}$

\section{Assessment of life quality}

There are many methods to calculate life quality of COPD patients, such as the St George's Respiratory Questionnaire (SGRQ), ${ }^{66}$ the Clinical COPD Questionnaire (CCQ), ${ }^{67}$ the COPD Assessment Test (CAT), ${ }^{68}$ and the Chronic Respiratory Questionnaire (CRQ) (Table 4). ${ }^{69}$ The MCID of the SGRQ, CCQ, CAT and CRQ is 4 units, 0.4 points, 2 points and 0.5 points for each domain, respectively, as an improvement for COPD treatment in clinical trials. ${ }^{70-73}$ In addition, the 36 -item short-form (SF-36) is a valid instrument to measure life quality in patients with COPD. ${ }^{74,75}$ Changes greater than 8.3 points are regarded as clinically important differences of the SF-36. ${ }^{76}$ Body mass index, airflow obstruction, dyspnea, and exercise capacity index (BODE) is a new multidimensional grading system to predict the mortality and stage and monitor progression in COPD patients. Patients with a BODE of 7-10 were shown to survive $\sim 3$ years. ${ }^{77,78} \mathrm{BODE}$ is also used to calculate the health-related quality of life in COPD patients. $^{79}$

\section{Exercise training}

Exercise training is beneficial for patients with COPD independent of age, gender, level of dyspnea, or disease severity. All COPD patients with decreased physical capacity or physical activity level should be recommended and offered exercise training. ${ }^{80}$ Various training types exist, and prescription should be individualized based on the patient's condition.

\section{Endurance exercise training}

Endurance exercise training improves exercise-induced hyperinflation and exertional dyspnea, heart rate recovery, and counteracting muscle dysfunction in COPD. ${ }^{81-83}$ Walking (either on a treadmill or the ground) or cycling (on a cycle

Table 4 Assessment of life quality in patients with COPD

\begin{tabular}{|c|c|c|c|c|}
\hline $\begin{array}{l}\text { Assessment } \\
\text { methods }\end{array}$ & Function & Advantage & Disadvantage & $M C I D / C I D$ \\
\hline $\mathrm{SGRQ}^{66,70}$ & $\begin{array}{l}\text { A gold standardized self- } \\
\text { completed questionnaire for } \\
\text { measuring quality of life }\end{array}$ & $\begin{array}{l}\text { Well validated and frequently } \\
\text { used in COPD trials }\end{array}$ & $\begin{array}{l}\text { Complicated and time consuming, } \\
\text { especially for older patients } \\
\text { Need special spreadsheets to } \\
\text { calculate the scores } \\
\text { Restricted in daily clinical practice }\end{array}$ & 4 units \\
\hline $\mathrm{CCQ}^{67,71}$ & $\begin{array}{l}\text { A self-administered } \\
\text { questionnaire specially developed } \\
\text { to measure clinical control }\end{array}$ & $\begin{array}{l}\text { Short and easy to complete, } \\
\text { usually tested in mild-to- } \\
\text { moderate COPD }\end{array}$ & $\begin{array}{l}\text { Skewed distributions in functional } \\
\text { and mental state domains }\end{array}$ & 0.4 \\
\hline $\mathrm{CAT}^{68,72}$ & $\begin{array}{l}\text { A patient-completed } \\
\text { questionnaire for assessing and } \\
\text { monitoring COPD }\end{array}$ & $\begin{array}{l}\text { Easier and faster to complete, } \\
\text { especially for patients with } \\
\text { low education level }\end{array}$ & $\begin{array}{l}\text { Need to testify in different patient } \\
\text { population characteristics, such as } \\
\text { females, patients with mild disease }\end{array}$ & 2 points \\
\hline $\mathrm{CRQ}^{69,73}$ & $\begin{array}{l}\text { An established measure of health } \\
\text { status including self-reported and } \\
\text { interviewer-led versions }\end{array}$ & $\begin{array}{l}\text { Demonstrates changes in } \\
\text { disability in older patients }\end{array}$ & $\begin{array}{l}\text { Lack of sensitivity in patients with } \\
\text { minor symptoms } \\
\text { Unable to make comparisons } \\
\text { between populations }\end{array}$ & 0.5 for each domain \\
\hline SF-36, version $2.0^{75,76}$ & $\begin{array}{l}\text { A self-administration } 36 \text {-item } \\
\text { short-form health survey }\end{array}$ & $\begin{array}{l}\text { Has good construct validity } \\
\text { and correlates well with } \\
\text { objective assessments of } \\
\text { health status. Completed in } \\
\text { person or by telephone }\end{array}$ & $\begin{array}{l}\text { Weak correlation with lung } \\
\text { function tests } \\
\text { Used less in clinical trials and } \\
\text { practice }\end{array}$ & 8.3 points \\
\hline $\mathrm{BODE}^{77,79}$ & $\begin{array}{l}\text { A simple multidimensional } \\
\text { grading system to predict the } \\
\text { risk of death and calculate the } \\
\text { life quality }\end{array}$ & $\begin{array}{l}\text { A better tool to predict } \\
\text { mortality and a significant } \\
\text { predictor of life quality in } \\
\text { patients with severe COPD }\end{array}$ & $\begin{array}{l}\text { Has not been widespread applied } \\
\text { now }\end{array}$ & - \\
\hline
\end{tabular}

Abbreviations: SGRQ, St George's Respiratory Questionnaire; CCQ, Clinical COPD Questionnaire; CAT, COPD Assessment Test; CRQ, Chronic Respiratory Questionnaire; BODE, body-mass index, airflow obstruction, dyspnea, and exercise capacity. 
ergometer) is commonly recommended as endurance training. Ground walking mainly increased endurance walking capacity compared with cycling. ${ }^{84}$ Upper limb training is also important in COPD patients, such as aerobic regimens that include arm cycle ergometer training. The biceps, triceps, deltoids, latissimus dorsi, and the pectorals are the typical muscles to be trained.

Breathlessness is the main important symptom after walking, while leg effort or fatigue of the quadriceps is an infrequent symptom in COPD. ${ }^{85}$ If the patient needs to improve walking capacity, ground walking can be the better choice. Bike training usually leads to quadriceps fatigability. Using one-legged cycle training reduces the total metabolic demand and improves aerobic capacity compared with conventional two-legged training in stable COPD patients. ${ }^{86}$ One-legged cycling is recommended as an option for exercise training in future professional PR guidelines.

The endurance training prescription recommended by the American Thoracic Society/European Respiratory Society is 20-60 minutes per session at $>60 \%$ maximal work rate, 3-5 times per week. ${ }^{8}$ The Borg scale can be used to monitor the intensity of exercise training, an exercise level with a score of 4-8 is closer to the target training intensity. ${ }^{87}$

\section{Resistance/strength training}

Muscle atrophy and weakness are common in patients with COPD, and endurance training has little effect on the two problems. Many studies found that strength training can improve not only muscle strength and quality of life but also exercise capacity in patients with COPD ${ }^{88,89}$ Free weights (eg, weight lifting, dumbbell, lead ball, etc.) or training with machines for arms and legs are common methods used in strength training. ${ }^{90}$ Paoli et al suggested that resistance training with multi-joint exercises (eg, bench press, deadlift, abdominal crunches, etc.) was more efficient for improving muscle strength. ${ }^{91}$ In daily activities, we should encourage patients to perform multi-joint exercises. Besides, single-joint exercise may be necessary to strengthen lumbar extensors and to correct muscular imbalances. ${ }^{92}$

O'Shea et al discovered that short-term progressive resistance exercise significantly enhanced muscle strength, which could be applied in daily activities.$^{93} \mathrm{With}$ regard to progressive resistance exercise, the American College of Sports Medicine recommends that, for novice training (untrained individuals), loads corresponding to a repetition range of 8-12 RM are appropriate. When the current workload can be performed for one to two repetitions over the desired target, a $2-10 \%$ increase in load is recommended. The training frequency should be $2-3$ days each week for novice training. ${ }^{94}$
Moreover, strength training combined with endurance training produces more improvements in muscle power and endurance performance and prevents cognitive decline and associated comorbidities, which is considered as an adequate training strategy for COPD patients. ${ }^{83,95}$

\section{Respiratory muscle training}

Respiratory muscle training, especially inspiratory muscle training (IMT), in patients with COPD induces an improvement in inspiratory muscle force and endurance, functional exercise capacity, dyspnea, and quality of life. ${ }^{96}$ In patients with inspiratory muscle weakness, IMT can be used as part of the treatment during PR. The most common approach to training the respiratory muscles uses resistive or threshold breathing devices, such as Threshold ${ }^{\mathrm{TM}}$ Inspiratory Muscle Trainer, PowerBreathe. ${ }^{97,98}$ Inspiratory resistive breathing and threshold loading are considered a mixture of strength and endurance training. Training intensity was usually set at an inspiratory load of $\geq 30 \% \operatorname{MIP}\left(\mathrm{P}_{\mathrm{I}}\right.$, max $) .{ }^{96}$ Other studies showed that high-intensity IMT is feasible in patients with moderate-to-severe COPD, significantly improving the respiratory muscle strength and endurance. ${ }^{99}$ Persistence with IMT is recommended because the benefits of training will decline gradually over time once IMT is stopped. ${ }^{97}$

In addition, IMT combined with specific expiratory muscle training improve respiratory muscle strength more than IMT only. ${ }^{100}$ However, whether combined training improves functional capacity and/or reduces dyspnea has not been demonstrated. More studies with larger sample sizes are needed to on this issue.

\section{Neuromuscular electrical stimulation (NMES)}

NMES is an alternative method of enhancing quadricep strength and exercise capacity in moderate-to-severe COPD patients. ${ }^{101}$ NMES uses various devices, such as lowfrequency current, medium-frequency current, monopolar pulses, bipolar pulses, and so forth. ${ }^{102}$ Previous studies have shown low-frequency $(15 \mathrm{~Hz})$ or high-frequency $(75 \mathrm{~Hz})$ NMES to be a suitable rehabilitative modality in severely dyspneic COPD patients. ${ }^{103}$ This finding is the same as a study implemented in patients with acute exacerbation of COPD at a frequency of 35 or $50 \mathrm{~Hz}$ NMES intensity. ${ }^{104}$ The exact frequency for patients with different stages of COPD needs to be determined by more additional studies with lager sample sizes and randomized trials. We may explore the benefits of NMES combined with other muscle trainings in the future. 


\section{Other training methods}

Tai Chi, derived from China as a systematic callisthenic exercise, is recognized as an exercise of moderate intensity in patients with COPD. It not only is safe but also obtains better functional capacity and pulmonary function as compared with usual care in people with COPD. ${ }^{105}$ At present, Tai Chi has various styles, with Chen, Yang, $\mathrm{Wu}$, and Sun styles the most commonly practiced. ${ }^{106}$ The training recommendation is that the exercise intensity of Tai Chi reaches a moderate level in people with COPD. A shortform Sun style is also applied in COPD, which achieves a moderate exercise intensity. ${ }^{107}$ Although different styles and forms of Tai Chi have been adopted in different studies, there is no accordant, simple, and effective style or form for COPD patients. Future studies should take this into consideration.

Yoga is an appropriate complementary therapy in patients with COPD because it consists of movement-coordinated breathing and low-impact fitness. ${ }^{108}$ Yoga programs improve exercise capacity and life quality, which have the same components and designs. It may be a useful adjunct to formal rehabilitation programs. ${ }^{109}$

There are many other training modalities, such as pursed lip breathing, ${ }^{110}$ water-based training, ${ }^{111}$ and so on. Various methods of training have emerged, and we should explore the best, most effective, and synthetic training system for patients with COPD.

\section{Conclusion}

Patients with COPD have varying degrees of activity limitation because of skeletal muscle dysfunction. Nonmedical staff, societies, and families should also pay attention to inactivity. There are many methods of exercise assessments for patients with COPD, choosing the most suitable method to calculate the situation of patients is crucial. In future, we may formulate a systemic and standardized measurement to assess COPD patients before starting PR. Moreover, developing an individualized exercise training prescription for COPD patients is our target. More studies are warranted to support the evidence and examine the effects of longterm benefits of exercise training for patients with COPD in each stage.

\section{Acknowledgment}

This manuscript was supported by the funding of the National Key Clinical Specialty Construction Projects of China.

\section{Disclosure}

The authors report no conflicts of interest in this work.

\section{References}

1. Global Initiative for Chronic Obstructive Lung Disease [webpage on the Internet]. Global strategy for the diagnosis, management, and prevention of COPD: GOLD 2017. Available from: http://goldcopd.org/ gold-2017-global-strategy-diagnosis-management-prevention-copd/ Global. Accessed December 20, 2017.

2. Mathers CD, Loncar D. Projections of global mortality and burden of disease from 2002 to 2030. PLoS Med. 2006;3(11):e442.

3. Kessler R, Partridge MR, Miravitlles M, et al. Symptom variability in patients with severe COPD: a pan-European cross-sectional study. Eur Respir J. 2011;37(2):264-272.

4. Singh S, Harrison S, Houchen L, Wagg K. Exercise assessment and training in pulmonary rehabilitation for patients with COPD. Eur J Phys Rehabil Med. 2011;47(3):483-497.

5. Casaburi R. Skeletal muscle function in COPD. Chest. 2000; 117(5 Suppl 1):267S-271S

6. O'Donnell DE, Webb KA. The major limitation to exercise performance in COPD is dynamic hyperinflation. J Appl Physiol (1985). 2008; 105(2): 753-755; discussion: 755-757.

7. Eisner MD, Blanc PD, Sidney S, et al. Body composition and functional limitation in COPD. Respir Res. 2007;8:7.

8. Spruit MA, Singh SJ, Garvey C, et al. An official American Thoracic Society/European Respiratory Society statement: key concepts and advances in pulmonary rehabilitation. Am J Respir Crit Care Med. 2013;188(8):e13-e64.

9. Puhan MA, Gimeno-Santos E, Scharplatz M, Troosters T, Walters EH, Steurer J. Pulmonary rehabilitation following exacerbations of chronic obstructive pulmonary disease. Cochrane Database Syst Rev. 2011;(10):CD005305.

10. McCarthy B, Casey D, Devane D, Murphy K, Murphy E, Lacasse Y. Pulmonary rehabilitation for chronic obstructive pulmonary disease. Cochrane Database Syst Rev. 2015;(2):CD003793.

11. Maltais F, Decramer M, Casaburi R, et al. An official American Thoracic Society/European Respiratory Society statement: update on limb muscle dysfunction in chronic obstructive pulmonary disease. Am J Respir Crit Care Med. 2014;189(9):e15-e62.

12. Barreiro E, Gea J. Molecular and biological pathways of skeletal muscle dysfunction in chronic obstructive pulmonary disease. Chron Respir Dis. 2016;13(3):297-311.

13. Whittom F, Jobin J, Simard PM, et al. Histochemical and morphological characteristics of the vastus lateralis muscle in patients with chronic obstructive pulmonary disease. Med Sci Sports Exerc. 1998; 30(10):1467-1474.

14. Gouzi F, Maury J, Molinari N, et al. Reference values for vastus lateralis fiber size and type in healthy subjects over 40 years old: a systematic review and meta-analysis. J Appl Physiol (1985). 2013;115(3): 346-354.

15. Marquis K, Debigare R, Lacasse Y, et al. Midthigh muscle crosssectional area is a better predictor of mortality than body mass index in patients with chronic obstructive pulmonary disease. Am J Respir Crit Care Med. 2002;166(6):809-813.

16. Soler-Cataluna JJ, Sanchez-SanchezL, Martinez-Garcia MA, Sanchez PR, Salcedo E, Navarro M. Mid-arm muscle area is a better predictor of mortality than body mass index in COPD. Chest. 2005;128(4): 2108-2115.

17. Plant PJ, Brooks D, Faughnan M, et al. Cellular markers of muscle atrophy in chronic obstructive pulmonary disease. Am J Respir Cell Mol Biol. 2010;42(4):461-471

18. Kythreotis P, Kokkini A, Avgeropoulou S, et al. Plasma leptin and insulin-like growth factor I levels during acute exacerbations of chronic obstructive pulmonary disease. BMC Pulm Med. 2009;9:11.

19. Laveneziana P, Palange P; ERS Research Seminar Faculty. Physical activity, nutritional status and systemic inflammation in COPD. Eur Respir J. 2012;40(3):522-529.

20. Rossi A, Aisanov Z, Avdeev S, et al. Mechanisms, assessment and therapeutic implications of lung hyperinflation in COPD. Respir Med. 2015;109(7):785-802. 
21. Calverley PM, Koulouris NG. Flow limitation and dynamic hyperinflation: key concepts in modern respiratory physiology. Eur Respir J. 2005;25(1):186-199.

22. O'Donnell DE, Revill SM, Webb KA. Dynamic hyperinflation and exercise intolerance in chronic obstructive pulmonary disease. Am J Respir Crit Care Med. 2001;164(5):770-777.

23. O'Donnell DE, Laveneziana P. Physiology and consequences of lung hyperinflation in COPD. Eur Respir Rev. 2006;15(100):61-67.

24. Peno-Green L, Verrill D, Vitcenda M, Macintyre N, Graham H. Patient and program outcome assessment in pulmonary rehabilitation: an AACVPR statement. J Cardiopulm Rehabil Prev. 2009;29(6): 402-410.

25. Bestall JC, Paul EA, Garrod R, Garnham R, Jones PW, Wedzicha JA. Usefulness of the Medical Research Council (MRC) dyspnoea scale as a measure of disability in patients with chronic obstructive pulmonary disease. Thorax. 1999;54(7):581-586.

26. Borg G. Psychophysical scaling with applications in physical work and the perception of exertion. Scand J Work Environ Health. 1990; 16(Suppl 1):55-58.

27. Borg GA. Psychophysical bases of perceived exertion. Med Sci Sports Exerc. 1982;14(5):377-381.

28. Khair RM, Nwaneri C, Damico RL, Kolb T, Hassoun PM, Mathai SC. The minimal important difference in Borg dyspnea score in pulmonary arterial hypertension. Ann Am Thorac Soc. 2016;13(6):842-849.

29. Mador MJ, Kufel TJ. Reproducibility of visual analog scale measurements of dyspnea in patients with chronic obstructive pulmonary disease. Am Rev Respir Dis. 1992;146(1):82-87.

30. Ries AL. Minimally clinically important difference for the UCSD Shortness of Breath Questionnaire, Borg Scale, and Visual Analog Scale. COPD. 2005;2(1):105-110.

31. Gift AG, Narsavage G. Validity of the numeric rating scale as a measure of dyspnea. Am J Crit Care. 1998;7(3):200-204.

32. Witek TJ Jr, Mahler DA. Minimal important difference of the transition dyspnoea index in a multinational clinical trial. Eur Respir J. 2003; 21(2):267-272.

33. McGavin CR, Artvinli M, Naoe H, McHardy GJ. Dyspnoea, disability, and distance walked: comparison of estimates of exercise performance in respiratory disease. $\mathrm{Br}$ Med J. 1978;2(6132):241-243.

34. ATS Committee on Proficiency Standards for Clinical Pulmonary Function Laboratories. ATS statement: guidelines for the six-minute walk test. Am J Respir Crit Care Med. 2002;166(1):111-117.

35. Holland AE, Spruit MA, Troosters T, et al. An official European Respiratory Society/American Thoracic Society technical standard: field walking tests in chronic respiratory disease. Eur Respir J. 2014;44(6): 1428-1446.

36. Singh SJ, Jones PW, Evans R, Morgan MD. Minimum clinically important improvement for the incremental shuttle walking test. Thorax. 2008;63(9):775-777.

37. Revill SM, Morgan MD, Singh SJ, Williams J, Hardman AE. The endurance shuttle walk: a new field test for the assessment of endurance capacity in chronic obstructive pulmonary disease. Thorax. 1999; 54(3):213-222.

38. Pepin V, Laviolette L, Brouillard C, et al. Significance of changes in endurance shuttle walking performance. Thorax. 2011;66(2):115-220.

39. Kon SS, Patel MS, Canavan JL, et al. Reliability and validity of 4-metre gait speed in COPD. Eur Respir J. 2013;42(2):333-340.

40. Kon SS, Canavan JL, Nolan CM, et al. The 4-metre gait speed in COPD: responsiveness and minimal clinically important difference. Eur Respir J. 2014;43(5):1298-1305.

41. Coquart JB, Lemaitre F, Castres I, Saison S, Bart F, Grosbois JM. Reproducibility and sensitivity of the 6-Minute Stepper Test in patients with COPD. COPD. 2015;12(5):533-538.

42. Pichon R, Couturaud F, Mialon P, et al. Responsiveness and minimally important difference of the 6-Minute Stepper Test in patients with chronic obstructive pulmonary disease. Respiration. 2016;91(5): 367-373.

43. Vaidya T, Chambellan A, de Bisschop C. Sit-to-stand tests for COPD: a literature review. Respir Med. 2017;128:70-77.
44. Crook S, Busching G, Schultz K, et al. A multicentre validation of the 1-min sit-to-stand test in patients with COPD. Eur Respir J. 2017;49(3).

45. American Thoracic Society; American College of Chest Physicians. ATS/ACCP statement on cardiopulmonary exercise testing. Am J Respir Crit Care Med. 2003;167(2):211-277.

46. Kaminsky LA, Imboden MT, Arena R, Myers J. Reference standards for cardiorespiratory fitness measured with cardiopulmonary exercise testing using cycle ergometry: data from the Fitness Registry and the Importance of Exercise National Database (FRIEND) Registry. Mayo Clin Proc. 2017;92(2):228-233.

47. Puente-Maestu L, Palange P, Casaburi R, et al. Use of exercise testing in the evaluation of interventional efficacy: an official ERS statement. Eur Respir J. 2016;47(2):429-460.

48. Ciesla N, Dinglas V, Fan E, Kho M, Kuramoto J, Needham D. Manual muscle testing: a method of measuring extremity muscle strength applied to critically ill patients. J Vis Exp. 2011;(50).

49. O'Shea SD, Taylor NF, Paratz JD. Measuring muscle strength for people with chronic obstructive pulmonary disease: retest reliability of hand-held dynamometry. Arch Phys Med Rehabil. 2007;88(1): 32-36.

50. Bohannon RW. Muscle strength: clinical and prognostic value of handgrip dynamometry. Curr Opin Clin Nutr Metab Care. 2015;18(5): 465-470.

51. Robles PG, Mathur S, Janaudis-Fereira T, Dolmage TE, Goldstein RS, Brooks D. Measurement of peripheral muscle strength in individuals with chronic obstructive pulmonary disease: a systematic review. J Cardiopulm Rehabil Prev. 2011;31(1):11-24.

52. Edwards RH, Young A, Hosking GP, Jones DA. Human skeletal muscle function: description of tests and normal values. Clin Sci Mol Med. 1977;52(3):283-290.

53. Swallow EB, Reyes D, Hopkinson NS, et al. Quadriceps strength predicts mortality in patients with moderate to severe chronic obstructive pulmonary disease. Thorax. 2007;62(2):115-120.

54. Levinger I, Goodman C, Hare DL, Jerums G, Toia D, Selig S. The reliability of the 1RM strength test for untrained middle-aged individuals. J Sci Med Sport. 2009;12(2):310-316.

55. Kaelin ME, Swank AM, Adams KJ, Barnard KL, Berning JM, Green A. Cardiopulmonary responses, muscle soreness, and injury during the one repetition maximum assessment in pulmonary rehabilitation patients. J Cardiopulm Rehabil. 1999;19(6):366-372.

56. Man WD, Soliman MG, Nikoletou D, et al. Non-volitional assessment of skeletal muscle strength in patients with chronic obstructive pulmonary disease. Thorax. 2003;58(8):665-669.

57. Klimathianaki M, Vaporidi K, Georgopoulos D. Respiratory muscle dysfunction in COPD: from muscles to cell. Curr Drug Targets. 2011; 12(4):478-488.

58. American Thoracic Society/European Respiratory Society. ATS/ERS statement on respiratory muscle testing. Am J Respir Crit Care Med. 2002;166(4):518-624.

59. Evans JA, Whitelaw WA. The assessment of maximal respiratory mouth pressures in adults. Respir Care. 2009;54(10):1348-1359.

60. Steier J, Kaul S, Seymour J, et al. The value of multiple tests of respiratory muscle strength. Thorax. 2007;62(11):975-980.

61. Laroche CM, Mier AK, Moxham J, Green M. The value of sniff esophageal pressures in the assessment of global inspiratory muscle strength. Am Rev Respir Dis. 1988;138(3):598-603.

62. Uldry C, Janssens JP, de Muralt B, Fitting JW. Sniff nasal inspiratory pressure in patients with chronic obstructive pulmonary disease. Eur Respir J. 1997;10(6):1292-1296.

63. Miller JM, Moxham J, Green M. The maximal sniff in the assessment of diaphragm function in man. Clin Sci (Lond). 1985;69(1):91-96.

64. Similowski T, Yan S, Gauthier AP, Macklem PT, Bellemare F. Contractile properties of the human diaphragm during chronic hyperinflation. N Engl J Med. 1991;325(13):917-923.

65. Polkey MI, Kyroussis D, Hamnegard CH, Mills GH, Green M, Moxham J. Diaphragm strength in chronic obstructive pulmonary disease. Am J Respir Crit Care Med. 1996;154(5):1310-1317. 
66. Jones PW, Quirk FH, Baveystock CM. The St George's Respiratory Questionnaire. Respir Med. 1991;85(Suppl B):25-31.

67. van der Molen T, Willemse BW, Schokker S, Ten HN, Postma DS, Juniper EF. Development, validity and responsiveness of the Clinical COPD Questionnaire. Health Qual Life Outcomes. 2003;1:13.

68. Jones PW, Harding G, Berry P, Wiklund I, Chen WH, Kline Leidy N. Development and first validation of the COPD Assessment Test. Eur Respir J. 2009;34(3):648-654.

69. Guyatt GH, Berman LB, Townsend M, Pugsley SO, Chambers LW. A measure of quality of life for clinical trials in chronic lung disease. Thorax. 1987;42(10):773-778.

70. Jones PW. St. George's Respiratory Questionnaire: MCID. COPD. 2005;2(1):75-79.

71. Kocks JW, Tuinenga MG, Uil SM, van den Berg JW, Stahl E, van der Molen T. Health status measurement in COPD: the minimal clinically important difference of the clinical COPD questionnaire. Respir Res. 2006;7:62.

72. Kon SS, Canavan JL, Jones SE, et al. Minimum clinically important difference for the COPD Assessment Test: a prospective analysis. Lancet Respir Med. 2014;2(3):195-203.

73. Schunemann HJ, Puhan M, Goldstein R, Jaeschke R, Guyatt GH. Measurement properties and interpretability of the chronic respiratory disease questionnaire (CRQ). COPD. 2005;2(1):81-89.

74. Ware JJ, Sherbourne CD. The MOS 36-item short-form health survey (SF-36). I. Conceptual framework and item selection. Med Care. 1992; 30(6):473-483.

75. Mahler DA, Mackowiak JI. Evaluation of the short-form 36-item questionnaire to measure health-related quality of life in patients with COPD. Chest. 1995;107(6):1585-1589.

76. Wyrwich KW, Fihn SD, Tierney WM, Kroenke K, Babu AN, Wolinsky FD. Clinically important changes in health-related quality of life for patients with chronic obstructive pulmonary disease: an expert consensus panel report. J Gen Intern Med. 2003;18(3):196-202.

77. Celli BR, Cote CG, Marin JM, et al. The body-mass index, airflow obstruction, dyspnea, and exercise capacity index in chronic obstructive pulmonary disease. N Engl J Med. 2004;350(10):1005-1012.

78. Cote CG, Celli BR. BODE index: a new tool to stage and monitor progression of chronic obstructive pulmonary disease. Pneumonol Alergol Pol. 2009;77(3):305-313.

79. Ong KC, Lu SJ, Soh CS. Does the multidimensional grading system (BODE) correspond to differences in health status of patients with COPD? Int J Chron Obstruct Pulmon Dis. 2006;1(1):91-96.

80. Emtner M, Wadell K. Effects of exercise training in patients with chronic obstructive pulmonary disease - a narrative review for FYSS (Swedish Physical Activity Exercise Prescription Book). Br J Sports Med. 2016;50(6):368-371.

81. Iepsen UW, Munch GD, Rugbjerg M, et al. Effect of endurance versus resistance training on quadriceps muscle dysfunction in COPD: a pilot study. Int J Chron Obstruct Pulmon Dis. 2016;11:2659-2669.

82. Gimeno-Santos E, Rodriguez DA, Barberan-Garcia A, et al. Endurance exercise training improves heart rate recovery in patients with COPD. COPD. 2014;11(2):190-196.

83. Chen R, Chen R, Chen X, Chen L. Effect of endurance training on expiratory flow limitation and dynamic hyperinflation in patients with stable chronic obstructive pulmonary disease. Intern Med J. 2014;44(8):791-800.

84. Leung RW, Alison JA, McKeough ZJ, Peters MJ. Ground walk training improves functional exercise capacity more than cycle training in people with chronic obstructive pulmonary disease (COPD): a randomised trial. J Physiother. 2010;56(2):105-112.

85. Man WD, Soliman MG, Gearing J, et al. Symptoms and quadriceps fatigability after walking and cycling in chronic obstructive pulmonary disease. Am J Respir Crit Care Med. 2003;168(5):562-567.

86. Dolmage TE, Goldstein RS. Effects of one-legged exercise training of patients with COPD. Chest. 2008;133(2):370-376.

87. Horowitz MB, Littenberg B, Mahler DA. Dyspnea ratings for prescribing exercise intensity in patients with COPD. Chest. 1996;109(5): $1169-1175$.
88. Mador MJ, Bozkanat E, Aggarwal A, Shaffer M, Kufel TJ. Endurance and strength training in patients with COPD. Chest. 2004;125(6): 2036-2045.

89. Vonbank K, Strasser B, Mondrzyk J, et al. Strength training increases maximum working capacity in patients with COPD - randomized clinical trial comparing three training modalities. Respir Med. 2012; 106(4):557-563.

90. Calik-Kutukcu E, Arikan H, Saglam M, et al. Arm strength training improves activities of daily living and occupational performance in patients with COPD. Clin Respir J. 2017;11(6):820-832.

91. Paoli A, Gentil P, Moro T, Marcolin G, Bianco A. Resistance training with single vs. multi-joint exercises at equal total load volume: effects on body composition, cardiorespiratory fitness, and muscle strength. Front Physiol. 2017;8:1105.

92. Gentil P, Fisher J, Steele J. A review of the acute effects and longterm adaptations of single- and multi-joint exercises during resistance training. Sports Med. 2017;47(5):843-855.

93. O'Shea SD, Taylor NF, Paratz JD. Progressive resistance exercise improves muscle strength and may improve elements of performance of daily activities for people with COPD: a systematic review. Chest. 2009;136(5):1269-1283.

94. American College of Sports Medicine Position Stand. Progression models in resistance training for healthy adults. Med Sci Sports Exerc. 2009;41(3):687-708.

95. Aquino G, Iuliano E, di Cagno A, et al. Effects of combined training vs aerobic training on cognitive functions in COPD: a randomized controlled trial. Int J Chron Obstruct Pulmon Dis. 2016;11: 711-718.

96. Gosselink R, De Vos J, van den Heuvel SP, Segers J, Decramer M, Kwakkel G. Impact of inspiratory muscle training in patients with COPD: what is the evidence? Eur Respir J. 2011;37(2):416-425.

97. Weiner P, Magadle R, Beckerman M, Weiner M, Berar-Yanay N. Maintenance of inspiratory muscle training in COPD patients: one year follow-up. Eur Respir J. 2004;23(1):61-65.

98. Basso-Vanelli RP, Di Lorenzo VA, Labadessa IG, et al. Effects of inspiratory muscle training and calisthenics-and-breathing exercises in COPD with and without respiratory muscle weakness. Respir Care. 2016;61(1):50-60.

99. Sturdy G, Hillman D, Green D, Jenkins S, Cecins N, Eastwood P. Feasibility of high-intensity, interval-based respiratory muscle training in COPD. Chest. 2003;123(1):142-150.

100. Neves LF, Reis MH, Plentz RD, Matte DL, Coronel CC, et al. Expiratory and expiratory plus inspiratory muscle training improves respiratory muscle strength in subjects with COPD: systematic review. Respir Care. 2014;59(9):1381-1388.

101. Chen RC, Li XY, Guan LL, et al. Effectiveness of neuromuscular electrical stimulation for the rehabilitation of moderate-to-severe COPD: a meta-analysis. Int J Chron Obstruct Pulmon Dis. 2016;11: 2965-2975.

102. Nussbaum EL, Houghton P, Anthony J, Rennie S, Shay BL, Hoens AM. Neuromuscular electrical stimulation for treatment of muscle impairment: critical review and recommendations for clinical practice. Physiother Can. 2017;69(5):1-76.

103. Sillen MJ, Wouters EF, Franssen FM, Meijer K, Stakenborg KH, Spruit MA. Oxygen uptake, ventilation, and symptoms during lowfrequency versus high-frequency NMES in COPD: a pilot study. Lung. 2011;189(1):21-26.

104. Chaplin EJ, Houchen L, Greening NJ, et al. Neuromuscular stimulation of quadriceps in patients hospitalised during an exacerbation of COPD: a comparison of low $(35 \mathrm{~Hz})$ and high $(50 \mathrm{~Hz})$ frequencies. Physiother Res Int. 2013;18(3):148-156.

105. Chan AW, Lee A, Lee DT, et al. The sustaining effects of Tai Chi Qigong on physiological health for COPD patients: a randomized controlled trial. Complement Ther Med. 2013;21(6):585-594.

106. Ngai SP, Jones AY, Tam WW. Tai Chi for chronic obstructive pulmonary disease (COPD). Cochrane Database Syst Rev. 2016;(6): CD009953. 
107. Leung RW, McKeough ZJ, Peters MJ, Alison JA. Short-form Sunstyle t'ai chi as an exercise training modality in people with COPD. Eur Respir J. 2013;41(5):1051-1057.

108. Selman L, McDermott K, Donesky D, Citron T, Howie-Esquivel J. Appropriateness and acceptability of a Tele-Yoga intervention for people with heart failure and chronic obstructive pulmonary disease: qualitative findings from a controlled pilot study. BMC Complement Altern Med. 2015;15:21.

109. Desveaux L, Lee A, Goldstein R, Brooks D. Yoga in the management of chronic disease: a systematic review and meta-analysis. Med Care. 2015;53(7):653-661.
110. Cabral LF, D’Elia TC, Marins DS, Zin WA, Guimaraes FS. Pursed lip breathing improves exercise tolerance in COPD: a randomized crossover study. Eur J Phys Rehabil Med. 2015;51(1):79-88.

111. McNamara RJ, McKeough ZJ, McKenzie DK, Alison JA. Waterbased exercise in COPD with physical comorbidities: a randomised controlled trial. Eur Respir J. 2013;41(6):1284-1291.

International Journal of COPD

\section{Publish your work in this journal}

The International Journal of COPD is an international, peer-reviewed journal of therapeutics and pharmacology focusing on concise rapid reporting of clinical studies and reviews in COPD. Special focus is given to the pathophysiological processes underlying the disease, intervention programs, patient focused education, and self management protocols.

\section{Dovepress}

This journal is indexed on PubMed Central, MedLine and CAS. The manuscript management system is completely online and includes a very quick and fair peer-review system, which is all easy to use. Visit $\mathrm{http}: / / \mathrm{www}$.dovepress.com/testimonials.php to read real quotes from published authors.

Submit your manuscript here: http://www.dovepress.com/international-journal-of-chronic-obstructive-pulmonary-disease-journal 